\title{
THE INTENSITY OF THE BACKGROUND VISUAL EFFECT OF CRISPENING DEPENDING ON BACKGROUND LIGHTNESS
}

\author{
Krunoslav Hajdek, Ivan Budimir, Nikola Mrvac
}

Preliminary communication

The paper presents the results of a research of the background visual effect of crispening depending on background lightness. A research on graphic reproductions with specifically designed solutions that involve the mentioned effect was conducted. Reproductions were designed through the variations of four different types of background lightness of 25\%, 50\%, 75\% and 100\% RTV (secondary stimuli), on which there are internal rectangles of lightness of $45 \%, 50 \%$ and $55 \%$ RTV (primary stimuli). The visual experiment was carried out through the use of the technique of simultaneous binocular harmonization with 10 respondents. The ANOVA with repeated measures revealed statistical differences between the arithmetic means of variations in lightness for four variations of the background in all three primary stimuli. Further post-hoc analysis by Fisher identified the groups that mutually differ. The results indicate the regularities to which the effect of crispening is subjected in the selected graphic medium. The research was conducted with the aim of standardizing the printing process during the appearance of crispening effect in real conditions of graphic production.

Key words: achromatic reproduction; ANOVA; crispening; psychophysics

Intenzitet pozadinskog vizulnog efekta nabiranja ovisno o svjetlini pozadine

Prethodno priopćenje

U radu su prezentirani rezultati istraživanja pozadinskog vizualnog efekta nabiranja u ovisnosti o svjetlini pozadine. Provedeno je istraživanje na grafičkim reprodukcijama sa specifično konstruiranim rješenjima u kojima se javlja spomenuti efekt. Reprodukcije su dizajnirane putem varijacija 4 različite pozadine svjetlina 25\%,50\%,75\% i 100\% RTV (sekundarni stimulus), na kojima se nalaze unutrašnji pravokutnici svjetlina $45 \%$, 50\% i 55\% RTV (primarni stimulusi). Vizualni eksperiment proveden je upotrebom tehnike simultanog binokularnog usuglašavanja sa 10 ispitanika. ANOVOM s ponovljenim mjerenjima utvrđene su statističke razlike među aritmetičkim sredinama odstupanja u svjetlinama za 4 varijacije pozadine i to kod sva 3 primarna stimulusa. Daljnjom post-hoc analizom po Fisheru identificirane su grupe koje se međusobno razlikuju. Dobiveni rezultati ukazuju na pravilnosti kojima se podvrgava efekt nabiranja u izabranom grafičkom mediju. Istraživanje je provedeno s ciljem standardizacije tiskarskog procesa prilikom pojavnosti efekta nabiranja u realnim uvjetima grafičke proizvodnje.

Ključne riječi: akromatska reprodukcija; ANOVA; nabiranje; psihofizika

\section{Introduction}

Various psychophysical visual effects have a big impact on the unwanted change in the manifestation of color on printing substrates and other media in the system of graphic reproduction $[1,2]$. The visual effects of crispening and simultaneous contrast are the effects that cause a shift in the manifestation of color, which is caused by the change of the background color; thus, a bright background causes a dark perception of the color of the observed stimuli, while a dark background causes the opposite [3]. The appearance of an image is affected by whether it is viewed with a light or a dark surround [4]. It is also known that the surround luminance of stimulus affects the manner in which the onscreen luminance levels are perceived [5]. It is also found that the surround luminance affects the perceived contrast of a stimulus [6]. Achromatic simultaneous contrast is based on the difference in lightness between the background and the observed stimuli, but what has also been determined to influence the existence of the effect are the mechanisms on which lateral inhibition is based [7, 8]. Chromatic simultaneous contrast is primarily based on the difference between the chromatic pairs of colors [9-12], and to a certain extent on chromatic adaptation. The crispening effect [13] occures in form in which a grey background enhances the sensitivity of the observer to lightness differences between grey samples of about the same lightness as that of background [14].

The effect of crispening was first discovered by a Japanese scientist Hiroshi Takasaki. Takasaki presented the results in 1966 showing that the contrast between two gray patches is enhanced if the background has brightness close to these patches „crispening effect" [15]. Scientist Paul Whittle observed the effect whereby luminance judgments are more sensitive around the background luminance, and in turn, judgments of luminance are based away from the background luminance, and he termed this the 'crispening' effect [16]. In his work Moroney also investigated the impact of background brightness on the perception [17].

The effect is defined as a psychophysical visual background effect that is largely connected with the previously described effect of simultaneous contrast [18] in which there is a shift of the relative perception of the lightness of the stimuli [19], i.e. an increase in the apparent strength of the intensity of the experience of color, which occurs between two compared different stimuli in situations when the color of the background on which the given stimuli are compared is very similar to the experience of the color of the stimuli [20].

If the three achromatic primary stimuli with the value of $20 \%, 25 \%$ and $30 \%$ RTV of the color black were to be compared on four different backgrounds (secondary stimuli), the mutual difference between the compared primary stimuli, and the perception thereof, would not be constant, it would vary depending on the color (lightness) on which the test is performed. The effect of crispening occurs when comparing two or more different chromatic stimuli in situations when backgrounds on which they are compared are perceptually similar to the stimuli - the socalled chromatic crispening [21]. Moreover, if in addition to the effect of crispening there are also the effects of chromatic adaptation and chromatic simultaneous 
contrast, what occurs is the effect called chromatic assimilation.

During the manifestation of psychophysical visual effects, determining the manifestation of color in communication systems is always based on the assessment of the psychophysical experience of one of the three (tone, saturation, and lightness) perceptual attributes of color that describe it $[22,23]$. The intensity of the effect is presented by calculated colorimetric color differences [24]. Psychophysical research primarily seeks to determine whether the respondent can detect a particular stimuli and compare it with another stimuli and describe the differences [20].

The idea of visual psychophysical research is to identify and define a particular perceptual reaction of the respondent induced by the stimuli of precisely defined physical characteristics that are instrumentally measurable [25]. The paper presents the results of the research on the background psychophysical effect of crispening. The research determined the extent to which the reproduced samples differ with respect to the predefined values of the color from the atlas. On the basis of the obtained results, the strength of the psychophysical visual effect of crispening for different variations of background lightness has been shown.

\section{Experimental part}

The experimental part of the research began with the development of a test sample which causes the manifestation of the crispening effect. The test sample for the evaluation of the crispening effect was derived in the following manner. The sample was created as an achromatic figure (stimuli) that causes the effect of crispening, the internal fields (primary stimuli) have values from the left to the right side of $45 \%, 50 \%$ and 55 $\%$ RTV of the color black, while the external fields, which essentially represent the background (secondary stimuli), have a value range from $25 \% \div 100 \%$ RTV of the color black in the increments of every next field of 25 $\%$ RTV from left to right (Fig. 1).

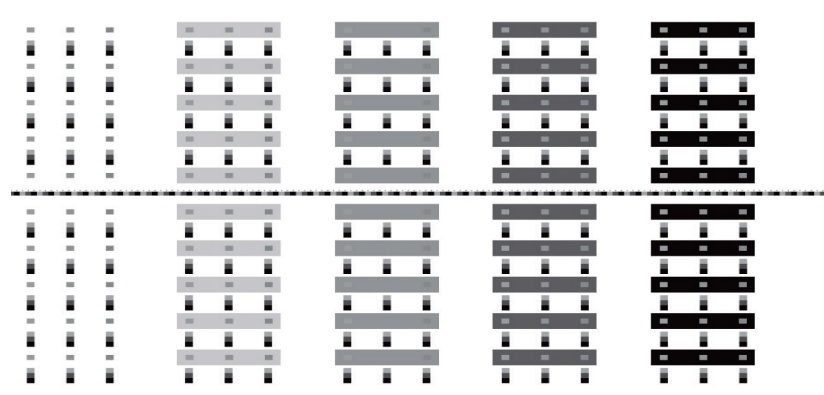

Figure 1 The design of the test form of the achromatic effect of crispening

On the sheet, there are horizontally three primary stimuli that surround the four secondary stimuli, while vertically the lines with the stimuli are propagated to the sheet range. As a part of the experiment, that involves a visual evaluation (technique of simultaneous binocular harmonization) [12] of the developed stimuli in the form of fields from the achromatic atlas, which the respondents have to assign to the primary stimuli that are located on the impression. Respondents (10) were given the instructions to assign the primary stimuli on the reproduction obtained according to the CIP3 values to the fields from the color atlas that they perceived to be the most similar. Only those who met the specific color test were able to participate in the research. Each respondent (experience operators on the printing machines, familiar with print quality evaluation) took the test ten times (when the tenth respondent finished assignment, evaluation started again from the start and thus ten times) and what was measured was the arithmetic mean of Lab values of the fields of the achromatic atlas assigned to the primary stimuli, that were taken into account in further measurements.

Printing was carried out on a calibrated machine for offset printing, and uncoated wood-free paper (bd. off. $140 \mathrm{~g} / \mathrm{m}^{2}$ ) was taken as a printing substrate. The ambient conditions of the space for visual evaluation were compliant with the guidelines of the ISO 3664:2009 norm $\left(0^{\circ}\right.$ viewing angle, $60 \mathrm{~cm}$ the distance of respondents from the test sample, a natural matt gray environment). The evaluation of the effect, i.e. the tuning of test samples, was conducted on a sample of 10 respondents, the average age of 23 years. The test form was printed on a calibrated machine for offset printing - Heidelberg Speedmaster SM 74-5-P by using the perceptual ICC rendering method. Rendering was done in Adobe Photoshop, where a transition from the Lab space of colors into the space of the colors of the profile for offset printing occurred. The Adobe (ACE) option was selected as a conversion option, and uncoated (wood-free offset) paper with the weight of $140 \mathrm{~g} / \mathrm{m}^{2}$ was used as a printing substrate. Before printing, the paper was conditioned in operation for 48 hours in the stipulated standard ambient conditions (temperature of $23{ }^{\circ} \mathrm{C}$ and relative humidity of $55 \%$ ). The achromatic atlas was made on a machine for the production of match prints, Espon Stylus Pro 4880, which was calibrated according to the curves for the calibration of a printing machine. The atlas was printed on the same type of printing substrate on which the impression was made. The achromatic atlas was made on the mentioned device to obtain as accurate comparison with the impression as possible. Namely, in real terms in printing houses, such devices are used for impression simulation, and they give very high accuracy between the reproduction obtained by printing on a printing press and the print obtained on the device for the production of match prints. With this type of atlas in the range of 2,5\% RTV, what is obtained is a more accurate comparison at the impression - match print correlation than it is the case with the existing (standard) atlas (Munsell) that does not have such a fineness of range between the fields. Precisely because of the created range of each field of 2,5 $\%$, a greater accuracy of the developed atlas was obtained, and hence, when examining the differences between the acquired reproduction and the atlas, more accurate results can be obtained than when using standard atlases.

The offset plate with the test form was manufactured by Kodak, and the plate type is Electra XD (thermal positive plate), with a spectral sensitivity from 800 to 850 $\mathrm{nm}$. The plate was made at a resolution of 175 lines and raster value of $2400 \mathrm{dpi}$ (AM raster), and the format of the plate is $745 \times 605 \mathrm{~cm}$. The device on which the offset 
plate was made is the platesetter Magnus Q800 Platesetter manufactured by Kodak. After the printing process, the first step is the visual comparison of the color atlas which was printed on the calibrated device for the production of match prints with a reproduction obtained according to the CIP3 values. The values of the internal fields on the impression were measured with the help of a spectrophotometer X Rite il Pro (a wavelength range from 380 to $730 \mathrm{~nm}$, the gas pressure of the light source of $2856 \mathrm{~K}$, the increment of $10 \mathrm{~nm}$, and the geometry of illumination of $45^{\circ} / 0^{\circ}$ ) and they were visually compared with the fields on the achromtic atlas on which the fields are designed so that each field has an increase in value of 2,5\% RTV compared to the previous field, starting with the first field on the atlas that has a value of $2,5 \%$ RTV to the last field that has a value of $100 \%$ RTV (Fig. 2). After the visual evaluation and association of the corresponding fields from the color atlas with the primary stimuli on the reproductions obtained according to the CIP3 values, the $\mathrm{CIE} \mathrm{Lab}$ values on the atlas and the reproduction were measured. Furthermore, $\Delta L_{00}, \Delta E_{00}$ were also calculated. After that, deviations of the obtained values of test fields (stimuli) in relation to the CIP3 reference values (spectrophotometric analysis and conversion to CIE Lab) were calculated on the obtained samples.

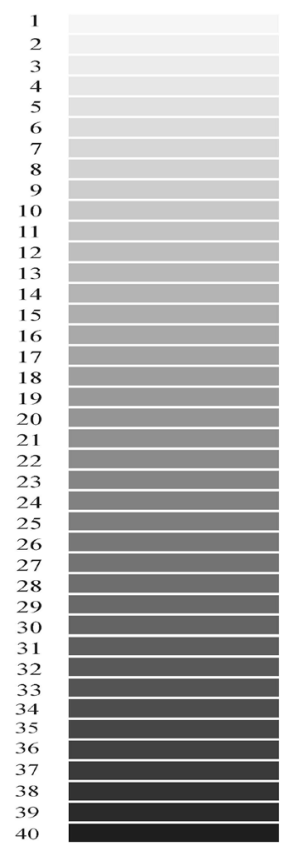

Figure 2 Atlas with achromatic tones

The results of the research of Lab values calculated with the help of the $\Delta E_{00}$ formula, were:

$$
\begin{aligned}
\Delta E_{00}= & {\left[\left(\frac{\Delta L^{\prime}}{k_{L} S_{L}}\right)^{2}+\left(\frac{\Delta C_{a b}^{\prime}}{k_{C} S_{C}}\right)^{2}+\left(\frac{\Delta H_{a b}^{\prime}}{k_{H} S_{H}}\right)^{2}+\right.} \\
& \left.+R_{T}\left(\frac{\Delta C_{a b}^{\prime}}{k_{C} S_{C}}\right)\left(\frac{\Delta H_{a b}^{\prime}}{k_{H} S_{H}}\right)\right]^{0,5},
\end{aligned}
$$

while the colorimetric differences of lightness $\Delta L_{00}$, chromaticity $\Delta C_{00}$, and tone $\Delta H_{00}$ are obtained with the help of the formulas:

$$
\begin{aligned}
& \Delta L^{\prime}=L_{b}^{\prime}-L_{s}^{\prime}, \\
& \Delta C_{a b}^{\prime}=C_{a b, b}^{\prime}-C_{a b, s}^{\prime}, \\
& \Delta H_{a b}^{\prime}=\left[2\left(C_{a b, b}^{\prime} C_{a b, s}^{\prime}\right)^{0,5} \sin \left(\frac{\Delta h_{a b}^{\prime}}{2}\right)\right] .
\end{aligned}
$$

\section{Research results}

This chapter presents the results of the testing of the effect of crispening for three primary stimuli (the internal squares of lightness of $45 \%, 50 \%$ and $55 \%$ RTV) for different background lightness. The lightness of backgrounds is $25 \%, 50 \%, 75 \%$ and $100 \%$ RTV. Below is the tabulation of the reference Lab values of the primary stimuli (Tab. $1 \div 3$ ) on different variations of backgrounds.

The results of Tab. $1 \div 3$ indicate the existence of very small differences between the Lab values of the referential primary stimuli that could not have been avoided due to the technical characteristics of the printing device, the background that surrounds the primary stimuli. Namely, because the primary stimuli and background are in the same area of coloration, the increase of paint application on the background automatically increases the paint application on the primary stimuli.

Table 1 An overview of the Lab values of the referential primary stimuli of $45 \%$ RTV on different variations of background lightness

\begin{tabular}{|c|c|c|c|}
\hline $\begin{array}{c}\text { Background } \\
(\mathrm{RTV})\end{array}$ & $L$ & $a$ & $b$ \\
\hline $25 \%$ & 59,2 & 1,4 & $-3,5$ \\
\hline $50 \%$ & 58,5 & 1,4 & $-3,5$ \\
\hline $75 \%$ & 57,9 & 1,4 & $-3,5$ \\
\hline $100 \%$ & 56,3 & 1,3 & $-3,5$ \\
\hline
\end{tabular}

Table 2 An overview of the Lab values of the referential primary stimuli of $50 \%$ RTV on different variations of background lightness

\begin{tabular}{|c|c|c|c|}
\hline $\begin{array}{c}\text { Background } \\
(\mathrm{RTV})\end{array}$ & $L$ & $a$ & $b$ \\
\hline $25 \%$ & 59,0 & 1,4 & $-3,5$ \\
\hline $50 \%$ & 58,1 & 1,4 & $-3,4$ \\
\hline $75 \%$ & 57,2 & 1,4 & $-3,4$ \\
\hline $100 \%$ & 56,0 & 1,3 & $-3,4$ \\
\hline
\end{tabular}

Table 3 An overview of the Lab values of the referential primary stimuli of 55\% RTV on different variations of background lightness

\begin{tabular}{|c|c|c|c|}
\hline $\begin{array}{c}\text { Background } \\
\text { (RTV) }\end{array}$ & $L$ & $a$ & $b$ \\
\hline $25 \%$ & 57,7 & 1,3 & $-3,5$ \\
\hline $50 \%$ & 56,2 & 1,3 & $-3,4$ \\
\hline $75 \%$ & 55,5 & 1,3 & $-3,4$ \\
\hline $100 \%$ & 55,2 & 1,3 & $-3,4$ \\
\hline
\end{tabular}

Accordingly, when measuring the Lab values of the referential primary stimuli for the effect of crispening, a tolerance of $\leq 4$ for the measured values of the referential primary stimuli has been determined.

The values of $\Delta L_{00}$ are presented as positive or negative, depending on whether the assigned field from the color atlas is darker than the primary stimulus that is located on the reproduction obtained according to CIP3 values, or lighter than the primary stimulus. 
Table 4 An overview of the obtained values of colorimetric differences between the primary stimuli and the assigned fields from the color atlas

\begin{tabular}{|c|c|c|c|c|c|}
\hline \multirow{2}{*}{$\begin{array}{c}\text { Lightness } \\
(\mathrm{RTV})\end{array}$} & $\begin{array}{c}\text { Primary } \\
\text { stimuli } \\
(\mathrm{RTV})\end{array}$ & $\Delta E_{00}$ & $\Delta L_{00}$ & $\Delta C_{00}$ & $\Delta H_{00}$ \\
\hline \multirow{3}{*}{$25 \%$} & $45 \%$ & 2,09 & 2,08 & 0,14 & 0,08 \\
\cline { 2 - 6 } & $50 \%$ & 2,03 & 1,99 & 0,35 & 0,10 \\
\cline { 2 - 6 } & $55 \%$ & 2,04 & 2,03 & 0,14 & 0,08 \\
\hline \multirow{3}{*}{$50 \%$} & $45 \%$ & 1,34 & $-1,33$ & $-0,01$ & 0,18 \\
\cline { 2 - 6 } & $50 \%$ & 1,35 & 1,28 & 0,34 & 0,28 \\
\cline { 2 - 6 } & $55 \%$ & 1,35 & 1,32 & 0,13 & 0,25 \\
\hline \multirow{3}{*}{$15 \%$} & $45 \%$ & 2,32 & $-2,31$ & $-0,01$ & 0,18 \\
\cline { 2 - 6 } & $50 \%$ & 2,26 & $-2,25$ & $-0,08$ & 0,23 \\
\cline { 2 - 6 } & $55 \%$ & 2,31 & $-2,31$ & $-0,01$ & 0,18 \\
\cline { 2 - 6 } & $45 \%$ & 2,64 & $-2,63$ & $-0,15$ & 0,10 \\
\cline { 2 - 6 } & $50 \%$ & 2,65 & $-2,65$ & $-0,15$ & 0,10 \\
\hline
\end{tabular}

\section{Discussion of research results}

A statistical analysis of all data obtained by the psychophysical visual experiment was carried out. To be more precise, what was analyzed were the value variations in lightness between the perceived and the physical lightness of the primary stimuli, i.e. the values of the variable $\Delta L_{00}$, on different backgrounds (lightness of
$25 \%, 50 \%, 75 \%$ and $100 \%$ RTV), that occur due to the crispening effect. The mentioned variations in lightness were calculated for all three primary stimuli (lightness of $45 \%, 50 \%$, and 55\% RTV). The lightness deviation measurement was defined as the arithmetic mean of the deviations observed by the respondents. The overall statistical analysis was carried out in the program STATISTICA 12 (StatSoft, Tulsa, USA). It consists of the calculation of the descriptive parameters of the differences in lightness, the Box and Whisher graphic display of results, the display of the results of the Kolmogorov-Smirnov test, and the results of ANOVA with repeated measures. A post-hoc analysis by Fisher was also carried out in order to identify the differences between arithmetic means.

\subsection{Descriptive statistics}

A descriptive statistical analysis of the differences in lightness $\left(\Delta L_{00}\right)$ that occur due to the crispening effect for different primary stimuli is shown in Tab. $5 \div 7$. It was done on the basis of samples obtained from the psychophysical visual experiment in which ten respondents took part.

Table 5 Descriptive statistics of the perceived difference in lightness (arithmetic mean \pm standard deviation $(\mu \pm \sigma)$, median $($ Med $)$, minimum $($ Min), maximum (Max), variance (Var)) for the primary stimuli of $45 \%$ RTV

\begin{tabular}{|c|c|c|c|c|c|}
\hline \multirow{2}{*}{$\begin{array}{c}\text { Background lightness } \\
\text { (RTV) }\end{array}$} & \multicolumn{5}{|c|}{$\begin{array}{c}\text { Descriptive statistics of the differences in lightness for the primary } \\
\text { stimuli of } 45 \% \text { RTV }\end{array}$} \\
\hline & $\mu \pm \sigma$ & Med & Min & $\operatorname{Max}$ & Var. \\
\hline $25 \%$ & $2,08 \pm 0,78$ & 2,08 & 1,35 & 2,82 & 0,60 \\
\hline $50 \%$ & $-1,32 \pm 1,21$ & $-1,32$ & $-2,47$ & $-0,18$ & 1,45 \\
\hline $75 \%$ & $-2,31 \pm 0,92$ & $-2,31$ & $-3,18$ & $-1,43$ & 0,85 \\
\hline $100 \%$ & $-2,61 \pm 1,77$ & $-2,61$ & $-4,56$ & $-0,65$ & 3,13 \\
\hline
\end{tabular}

Table 6 Descriptive statistics of the perceived difference in lightness (arithmetic mean \pm standard deviation $(\mu \pm \sigma)$, median $($ Med $)$, minimum $($ Min), maximum (Max), variance (Var)) for the primary stimuli of $50 \%$ RTV

\begin{tabular}{|c|c|c|c|c|c|}
\hline $\begin{array}{c}\text { Background lightness } \\
\text { (RTV) }\end{array}$ & \multicolumn{5}{|c|}{$\begin{array}{c}\text { Descriptive statistics of the differences in lightness for the primary } \\
\text { stimuli of 50\% RTV }\end{array}$} \\
\cline { 2 - 6 } & $\mu \pm \sigma$ & Med & Min & Max & Var. \\
\hline $25 \%$ & $2,00 \pm 0,63$ & 2,00 & 1,26 & 2,74 & 0,39 \\
\hline $50 \%$ & $1,28 \pm 0,62$ & 1,28 & 0,36 & 2,21 & 0,38 \\
\hline $75 \%$ & $-2,24 \pm 0,95$ & $-2,25$ & $-3,21$ & $-1,27$ & 0,90 \\
\hline $100 \%$ & $-2,64 \pm 1,15$ & $-2,64$ & $-3,88$ & $-1,38$ & 1,33 \\
\hline
\end{tabular}

Table 7 Descriptive statistics of the perceived difference in lightness (arithmetic mean \pm standard deviation $(\mu \pm \sigma)$, median $($ Med $)$, minimum $(M i n)$, maximum (Max), variance (Var)) for the primary stimuli of $55 \%$ RTV

\begin{tabular}{|c|c|c|c|c|c|}
\hline \multirow{2}{*}{$\begin{array}{c}\text { Background lightness } \\
\text { (RTV) }\end{array}$} & \multicolumn{5}{|c|}{$\begin{array}{c}\text { Descriptive statistics of the differences in lightness for the primary } \\
\text { stimuli of 55\% RTV }\end{array}$} \\
\cline { 2 - 6 } & $\mu \pm \sigma$ & Med & Min & Max & Var. \\
\hline $25 \%$ & $2,04 \pm 0.68$ & 2,04 & 1,19 & 2,88 & 0,47 \\
\hline $50 \%$ & $1,32 \pm 0.60$ & 1,32 & 0,75 & 1,89 & 0,36 \\
\hline $75 \%$ & $-2,30 \pm 0.87$ & $-2,30$ & $-3,29$ & $-1,30$ & 0,75 \\
\hline $100 \%$ & $-2,67 \pm 1.24$ & $-2,67$ & $-3,84$ & $-1,49$ & 1,53 \\
\hline
\end{tabular}

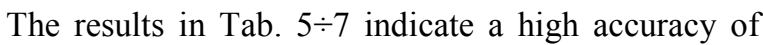
the results obtained by the experiment. Namely, the values of standard deviations and variances are very small for all samples (except for the primary stimuli of $45 \%$ RTV on the background with lightness of $100 \%$ RTV where the deviation is a bit bigger). Furthermore, all ranges between the minimum and the maximum are relatively small. The arithmetic means and medians are almost identical for all samples in all the observed background lightnesses.

Furthermore, a graphic Box and Whisker overview of arithmetic means (Fig. $3 \div 5$ ) can be seen. They also contain a graphic overview of the ranges $\mu \pm \sigma$ and $\mu \pm 1,96 \sigma$. 


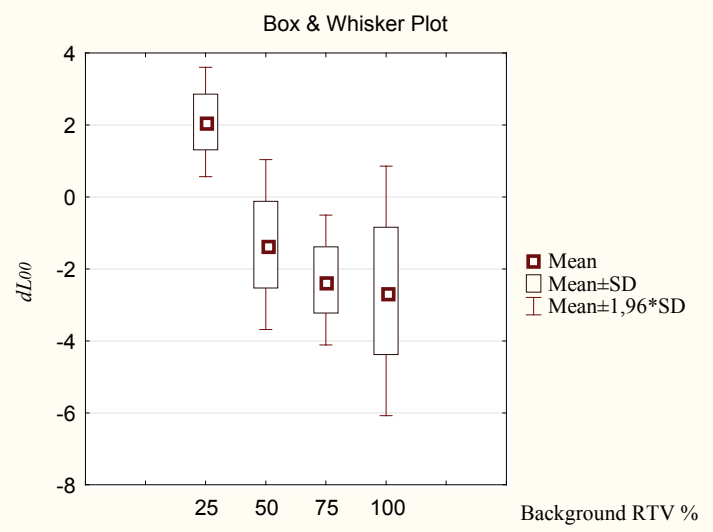

Figure 3 Box and Whisher graphical representation of deviations in lightness for the primary stimuli of $45 \%$ RTV

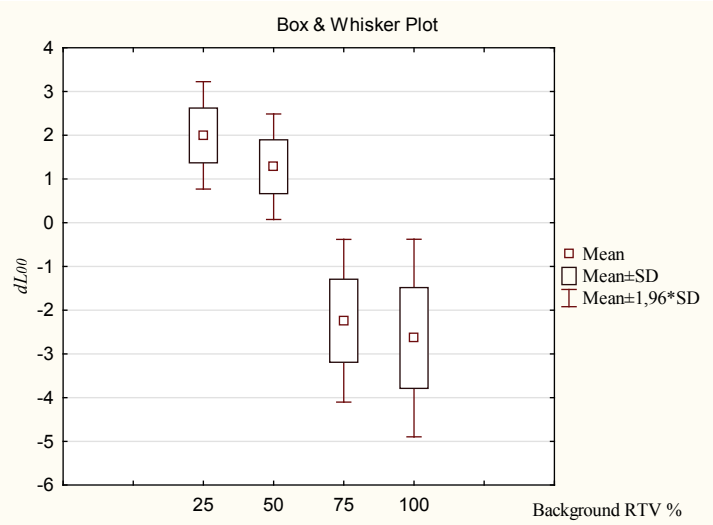

Figure 4 Box and Whisher graphical representation of deviations in lightness for the primary stimuli of $50 \%$ RTV

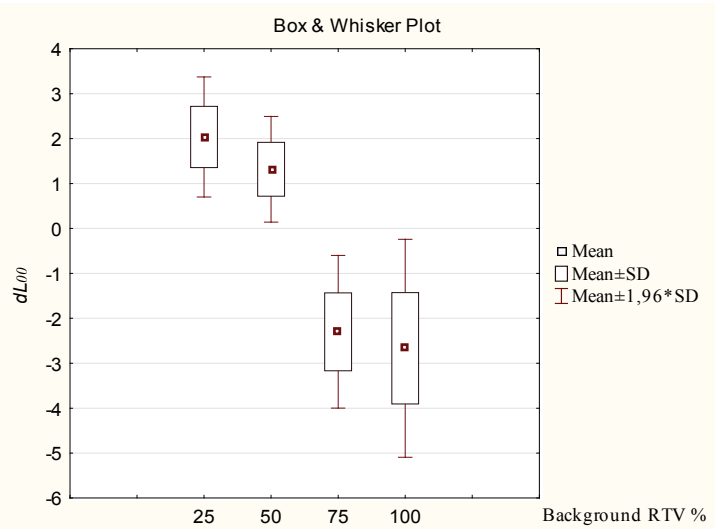

Figure 5 Box and Whisher graphical representation of deviations in lightness for the primary stimuli of $55 \%$ RTV

\subsection{ANOVA analysis for repeated measures}

Furthermore, the compliance of all the obtained data with the law of normal distribution was verified. For that purpose, the Kolmogorov-Smirnov test was applied on all samples whose results are shown in Tab. $8 \div 10$.

Table 8 Results of the Kolmogorov-Smirnov test (Max D statistics, empirical $p$-value) for the primary stimuli of $45 \%$ RTV

\begin{tabular}{|c|c|c|}
\hline $\begin{array}{c}\text { Background lightness } \\
(\mathrm{RTV})\end{array}$ & $\operatorname{Max} D$ & $\mathrm{~K}-\mathrm{S} p$ \\
\hline $25 \%$ & 0,33 & $p<0,20$ \\
\hline $50 \%$ & 0,33 & $p<0,20$ \\
\hline $75 \%$ & 0,33 & $\mathrm{p}<0,20$ \\
\hline $100 \%$ & 0,32 & $p>0,20$ \\
\hline
\end{tabular}

Table 9 Results of the Kolmogorov-Smirnov test (Max D statistics, empirical $p$-value) for the primary stimuli of $50 \% \mathrm{RTV}$

\begin{tabular}{|c|c|c|}
\hline $\begin{array}{c}\text { Background lightness } \\
(\mathrm{RTV})\end{array}$ & Max $D$ & $\mathrm{~K}-\mathrm{S} p$ \\
\hline $25 \%$ & 0,31 & $p>0,20$ \\
\hline $50 \%$ & 0,27 & $p>0,20$ \\
\hline $75 \%$ & 0,25 & $p>0,20$ \\
\hline $100 \%$ & 0,26 & $p>0,20$ \\
\hline
\end{tabular}

Table 10 Results of the Kolmogorov-Smirnov test (Max D statistics, empirical $p$-value) for the primary stimuli of $55 \% \mathrm{RTV}$

\begin{tabular}{|c|c|c|}
\hline $\begin{array}{c}\text { Background lightness } \\
(\mathrm{RTV})\end{array}$ & Max $D$ & K-S $p$ \\
\hline $25 \%$ & 0,26 & $p>0,20$ \\
\hline $50 \%$ & 0,33 & $p<0,20$ \\
\hline $75 \%$ & 0,20 & $p>0,20$ \\
\hline $100 \%$ & 0,33 & $p<0,20$ \\
\hline
\end{tabular}

The Kolmogorov-Smirnov test confirmed the compliance of all samples, for all three types of lightness of the primary stimulus, which is a prerequisite for the implementation of the ANOVA analysis.

Given that almost all variables are in line with the law of normal distribution, the ANOVA analyses with

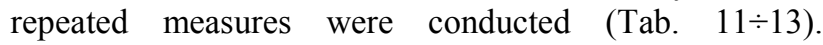
ANOVA statistically tested the differences between the arithmetic means of the visual perception of the deviation of lightness between the perceived and the physical value of the primary stimuli, for all three values of the primary stimuli. With it, the differences in the intensity of the effect of crispening depending on different background lightness were determined.

Table 11 Results of the ANOVA analysis for repeated measures for the

\begin{tabular}{|c|c|c|c|c|c|}
\hline \multicolumn{7}{|c|}{ primary stimuli of 45\% RTV } \\
\hline Effect & SS & Freedom degrees & $M S$ & $F$ & $p$ \\
\hline R1 & 139,18 & 3 & 46,39 & 37,88 & 0,00 \\
\hline Error & 33,07 & 27 & 1,22 & & \\
\hline
\end{tabular}

It was determined that the corresponding $F$-value is $F=37,88$ with a statistical significance of the $F$-test that is $p=0,00<0,05$ (Tab. 11). Therefore, the previous test showed that there are statistically significant differences between the arithmetic means of the results of the visual experiment, for the primary stimuli of lightness of $45 \%$ RTV.

Table 12 Results of the ANOVA analysis for repeated measures for the primary stimuli of $50 \%$ RTV

\begin{tabular}{|c|c|c|c|c|c|}
\hline Effect & SS & Freedom degrees & $M S$ & $F$ & $p$ \\
\hline R1 & 169,66 & 3 & 56,55 & 83,66 & 0,00 \\
\hline Error & 18,25 & 27 & 0,68 & & \\
\hline
\end{tabular}

ANOVA determined that the corresponding F-value is $F=83,66$ with a statistical significance of the F-test that is $p=0,00<0,05$ (Tab. 12). Therefore, the previous test showed that there are statistically significant differences between the arithmetic means of the deviations in lightness, for the primary stimuli of lightness of $50 \%$ RTV.

It was determined that the corresponding F-value is $F=67,46$ with a statistical significance of the F-test that is $p=0,00<0,05$ (Tab. 13). Therefore, the previous test showed that there are statistically significant differences between the arithmetic means of the deviations in 
lightness of the results of the visual experiment, for the primary stimuli of lightness of 55\% RTV.

Table 13 Results of the ANOVA analysis for repeated measures for the primary stimuli of $55 \%$ RTV

\begin{tabular}{|c|c|c|c|c|c|}
\hline Effect & $S S$ & Freedom degrees & $M S$ & $F$ & $p$ \\
\hline R1 & 176,38 & 3 & 58,79 & 67,46 & 0,00 \\
\hline Error & 23,53 & 27 & 0,87 & & \\
\hline
\end{tabular}

Furthermore, post-hoc analyses by Fisher (Tab. $14 \div 16$ ) were also conducted in order to identify the groups whose arithmetic means of lightness differences statistically significantly differ $(p<0,05)$. The analyses were carried out for all three primary stimuli.

Table 14 Results of the post-hoc analysis by Fisher for the primary stimuli of $45 \%$ RTV

\begin{tabular}{|c|c|c|c|}
\hline \multirow{2}{*}{$\begin{array}{c}\text { Background } \\
\text { lightness (RTV) }\end{array}$} & \multicolumn{3}{|c|}{ Probabilities for the post-hoc test } \\
\cline { 2 - 4 } & $25 \%$ & $50 \%$ & $75 \%$ \\
\hline $25 \%$ & - & - & - \\
\hline $50 \%$ & 0,000 & - & - \\
\hline $75 \%$ & 0,000 & 0,057 & - \\
\hline $100 \%$ & 0,000 & 0,015 & 0,543 \\
\hline
\end{tabular}

The post-hoc analysis by Fisher shows that the arithmetic means of differences in lightness $\left(\Delta L_{00}\right)$ statistically do not significantly differ for the pair with background lightness of $50 \%$ and $75 \%$ RTV, and the pair with background lightness of $75 \%$ and $100 \%$ RTV (Tab. 14). All other pairs statistically significantly differ $(p 0,00<0,05)$.

Table 15 Results of the post-hoc analysis by Fisher for the primary stimuli of $50 \%$ RTV

\begin{tabular}{|c|c|c|c|}
\hline \multirow{2}{*}{$\begin{array}{c}\text { Background } \\
\text { lightness } \\
\text { (RTV) }\end{array}$} & \multicolumn{3}{|c|}{ Probabilities for the post-hoc test } \\
\cline { 2 - 4 } & $25 \%$ & $50 \%$ & $75 \%$ \\
\hline $25 \%$ & - & - & - \\
\hline $50 \%$ & 0,062 & - & - \\
\hline $75 \%$ & 0,000 & 0,000 & - \\
\hline $100 \%$ & 0,000 & 0,000 & 0,292 \\
\hline
\end{tabular}

The post-hoc analysis by Fisher shows that the arithmetic means of differences in lightness $\left(\Delta L_{00}\right)$ statistically do not significantly differ for the pair with background lightness of $25 \%$ and $50 \%$ RTV, and the pair with background lightness of $75 \%$ and $100 \%$ RTV (Tab. 15). All other pairs statistically significantly differ $(p 0,00<0,05)$.

Table 16 Results of the post-hoc analysis by Fisher for the primary stimuli of $55 \%$ RTV

\begin{tabular}{|c|c|c|c|}
\hline \multirow{2}{*}{$\begin{array}{c}\text { Background } \\
\text { lightness (RTV) }\end{array}$} & \multicolumn{3}{|c|}{ Probabilities for the post-hoc test } \\
\cline { 2 - 4 } & $25 \%$ & $50 \%$ & $75 \%$ \\
\hline $25 \%$ & - & - & - \\
\hline $50 \%$ & 0,097 & - & - \\
\hline $75 \%$ & 0,000 & 0,000 & - \\
\hline $100 \%$ & 0,000 & 0,000 & 0,387 \\
\hline
\end{tabular}

The post-hoc analysis by Fisher shows that the arithmetic means of differences in lightness $\left(\Delta L_{00}\right)$ statistically do not significantly differ for the pair with background lightness of $25 \%$ and $50 \%$ RTV, and the pair with background lightness of $75 \%$ and $100 \%$ RTV
(Tab. 16). All other pairs statistically significantly differ $(p<0,05)$.

For the primary stimuli of $45 \%$ RTV with the background lightness of $25 \%$ the effect of crispening is reflected in the shift of the manifestation of lightness whose arithmetic mean is $\mu_{25}=2,08$, with an identical value of the median $\operatorname{Med}_{25}=2,08$ (Tab. 5). In this case, due to the crispening effect, the primary stimulus is perceived as darker than its physical value.

The arithmetic mean of the deviations in the lightness on the background of $25 \%$ RTV is statistically significantly different from all other arithmetic means (Tab. 14). Due to the same effect, with the lightness of $50 \%, 75 \%$, and $100 \%$ RTV the primary stimulus is perceived as brighter than its physical value. The corresponding arithmetic means and medians are $\mu_{50}=-1,32, \operatorname{Med}_{50}=-1,32, \mu_{75}=-2,31, \operatorname{Med}_{75}=-2,31$. The crispening effect is most strongly manifested with the background lightness of $100 \%$ RTV where its arithmetic mean is $\mu_{100}=-2,61$ with the corresponding median of the identical figure $\operatorname{Med}_{100}=-2,61$. However, there are no statistically significant differences between arithmetic means on backgrounds of $75 \%$ and $100 \%$ RTV.

In the case of the primary stimulus of lightness of 50 $\%$ RTV, the stimulus is perceived as darker with the background lightness of $25 \%$ and $50 \%$ RTV (Tab. 6). On those backgrounds, the arithmetic means of the shift of the manifestation of lightness are $\mu_{25}=2,00$ and $\mu_{50}=1,28$ with the medians of identical figures $\operatorname{Med}_{25}=2,00$ and $\operatorname{Med}_{50}=1,28$. The post-hoc analysis by Fisher did not identify any statistically significant differences between the two previous arithmetic means (Tab. 15). Due to the crispening effect, the primary stimulus is perceived as brighter on backgrounds with the lightness of $75 \%$ and $100 \%$ RTV. On the background of $75 \%$ RTV, the arithmetic mean of the shift of lightness is $\mu_{75}=-2,24$ with a median $\operatorname{Med}_{75}=-2,25$. The crispening effect is most strongly manifested on a background lightness of $100 \%$ RTV on which its arithmetic mean has the value $\mu_{100}=-2,64$ with a median of an identical figure $\operatorname{Med}_{100}=$ $-2,64$. However, on those backgrounds, the arithmetic means do not statistically significantly differ.

The third primary stimulus with the lightness of 55\% RTV is perceived as darker on backgrounds of $25 \%$ and $50 \%$ RTV, while on the backgrounds of $75 \%$ and $100 \%$ RTV (Tab. 7), it is perceived as brighter. On backgrounds of $25 \%$ and $50 \% \mathrm{RTV}$, the crispening effect is manifested as a shift in the manifestation of lightness whose arithmetic means are $\mu_{25}=2,04$ and $\mu_{50}=1,32$. Moreover, the medians are of identical figures $\operatorname{Med}_{25}=2,04$ and $\operatorname{Med}_{50}=1,32$. The previous two arithmetic means do not statistically significantly differ (Tab. 16). Furthermore, with the background lightness of $75 \%$ and $100 \%$ RTV, the crispening effect is manifested as the arithmetic mean of the shift in lightness of $\mu_{75}=-2,30$ and $\mu_{100}=-2,67$. The corresponding medians are identical $\operatorname{Med}_{75}=-2,30$ and $\operatorname{Med}_{100}=-2,67$. For the two previous arithmetic means, statistically significant differences have not been identified. 


\section{Conclusion}

The paper presents the results of a research of the background visual effect of crispening, which is manifested in a particular graphic medium. The results were obtained on the basis of a verified experimental method of simultaneous binocular harmonization through which the psychophysical visual experiment was conducted. The statistical analysis that was carried out on the results of the experiment clearly shows the numerical intensity and direction of the deviation in lightness between the perceived and the physical value of the primary stimuli $(45 \%, 50 \%$ and $55 \%$ RTV) depending on the change of background lightness $(25 \%, 50 \%, 75 \%$ and $100 \%$ RTV).

The measured values are variations in brightness between $\Delta L_{00}$ reproduction obtained according to CIP3 values and achromatic color atlas and the difference between them is calculated. The results indicate that the strength of the appearance of the crispening effect varies depending on the brightness of the secondary stimulus. Thus it can be seen that the differences in values $\Delta L_{00}$ are smallest among the three primary stimuli on background value of $50 \%$ RTV, precisely because the secondary stimulus is very similar to the primary stimulus, so the subjects can easier determine the field of color atlas. The maximum deviation is at the background value of $100 \%$ RTV, where the crispening effect is the most prominent. Results of the work present one step in the production process of making the reproduction in real graphic production.

The goal of the paper was to show how on achromatic reproduction on a particular printing substrate the effect of crispening affects the perception of brightness of primary stimulus when changing the brightness of the background (secondary stimulus). Specifically, the paper simulated real conditions which are used in graphic production. It was examined in what volume the deviation in a printed reproduction of pre-defined Lab values is in relation to the achromatic color atlas that represented the best proof (match print) by which contracting authority can see how it should look when the reproduction is printed. As graphic designers come up with all the innovative solutions that give their product advantages over the other, they resort to the use of certain "unfavourable" solutions for the process of getting graphic reproduction. Accordingly, the results of this work could contribute to minimizing or identifying possible deviations between the original and the reproduction during the appearance of background effects and standardizing certain processes in the manufacture of graphic solutions.

In order to provide even greater standardization of real graphic production process during the influence of psychophysical effects, visual research is planned to expand on chromatic and desaturated reproductions and include more printing substrates.

The obtained results may enable efficient anticipation of the crispening effect and a precise calculation of its magnitude in the mentioned production conditions, set out in the paper. Moreover, the statistical methodology applied in the paper can be effectively applied in the research of other visual effects.

\section{References}

[1] Kitaoka, A. Proceedings of the 11th Congress of the International Colour Association (AIC 2009) // A brief classification of colour illusions. / Sydney, 2009.

[2] Oicherman, B.; Luo, M. R.; Rigg B.; Robertson, A. R. Adaptation and colour matching of display and surface colours. // Color Research \& Application. 34, 3 (2009), pp. 182-193. https://doi.org/10.1002/col.20492

[3] Belaid, N.: Martens, J. B. Grey scale, the "crispening effect", and perceptual linearization. // Signal Processing. 70, 3(1998), pp. 231-245. https://doi.org/10.1016/S0165-1684(98)00126-1

[4] Fairchild, M. D. Considering the surround in device independent color imaging. // Color Research and Application. 20, 6(1995), pp. 352-363. https://doi.org/10.1002/col.5080200604

[5] Bartleson, C. J.; Breneman, E. J. Brightness perception in complex fields. // JOSA. 57, 7(1967) pp. 953-956. https://doi.org/10.1364/JOSA.57.000953

[6] Barten, P. G. J. Evaluation of subjective image quality with the square-root integral method. // JOSA. 7, 10(1990) pp. 2024-2031. https://doi.org/10.1364/JOSAA.7.002024

[7] Milković, M.; Zjakić, I.; Vusić, D. Kolorimetrija u multimedijskim komunikacijama, Polytechnic of Varaždinu, Varaždin, 2010.

[8] Li, A.; Tavantzis, M. J.; Yazdanbakhsh, A. Lightness of Munker-White illusion and Simultaneous- Contrast illusion: Establishing an ordinal lightness relation among minimum and split-frame presentations. // Review of Psychology. 16, 1(2009), pp. 3-8.

[9] Fairchild, M. D. Color Appearance Models, 2nd Ed., John Wiley \& Sons Ltd, UK, 2005.

[10] Reinhard, E.; Khan, A.E.; Akyüz, A, O. and Johnson, G. Color Imaging: Fundamentals and Applications, AK Peters, Ltd. Wellesley, Massachusetts, 2008.

[11] Cornelissen, F. W.; Brenner, E. Simultaneous colour constancy revisited: An analysis of viewing strategies. // Vision Research. 35(1995), pp. 2431-2448. https://doi.org/10.1016/0042-6989(94)00318-1

[12] Gage, J. Colour and Culture, Practice and Meaning from Antiquity to Abstraction, Thames and Hudson, 1993, pp. 173-176.

[13] Kaneko, T. A Reconsideration of Cobb-Judd Lightness Function. // Acta Chromatica. 1, (1964), pp. 103-110.

[14] Cui, G.; Luo, M. R.; Rigg, B. 'Crispening Effect' on lightness differences, Proc. SPIE 4421, 9th Congress of the International Colour Association, (6 June 2002); pp 634637. https://doi.org/10.1117/12.464720

[15] Takashi, H. Lightness change of gray induced by change in reflectance of gray background. // Journal of the Optical Society of America. 56, 4(1966), pp. 504-509. https://doi.org/10.1364/JOSA.56.000504

[16] Wittle, P. Brightness, discriminability and the 'crispening effect'// Vision Research. 32, 8(1992), pp. 1493-1507. https://doi.org/10.1016/0042-6989(92)90205-W

[17] Moroney, N. Background and the Perception of Lightness, Proc. SPIE 4421, 9th Congress of the International Colour Association, (6 June 2002). https://doi.org/10.1117/12.464574

[18] Kuehni, R. G. Color Space and Its Divisions, John Wiley \& Sons, New York, 2003.

[19] Budimir, I. Nove varijacije Munker-Whiteovog efekta u procesu grafičke komunikacije, Ph.D. thesis, Zagreb, 2015. https://doi.org/10.1002/0471432261

[20] Milković, M.; Mrvac, N.; Vusić, D. Vizualna psihofizika i dizajn, Polytechnic of Varaždin, Varaždin, 2009.

[21] Adelson, E. H. Perceptual Organization and the Judgment of Brightness. // Science. 262, (1993), pp. 2042 -2044. https://doi.org/10.1126/science.8266102 
[22] Malacara, D. Color Vision and Colorimetry: Theory and Applications, Spie Press, Washington, 2002.

[23] Milković, M. Evaluacija odnosa psihofizikalno determiniranih vizualnih efekata i metoda prevođenja gamuta, Ph.D. thesis, Zagreb, 2006.

[24] Vusić, D.; Mrvac, N.; Milković, M. The neon color spreading effect in various surround ambient conditions. // Technical Gazette. 18, 2(2011), pp. 219-225.

[25] Wu, R. C.; Wardman, R. H.; Luo, M. R. A Comparison of Lightness Contrast Effects in CRT and Surface Colours. // Color Research and Application. 30, (2004), pp. 13-20. https://doi.org/10.1002/col.20074

\section{Authors' addresses}

\section{dr. sc. Krunoslav Hajdek}

University North

University center Varaždin

104. brigade 3, 42000 Varaždin, Croatia

E-mail: krunoslav.hajdek@unin.hr

dr. sc. Ivan Budimir

Faculty of Graphic Arts

Getaldićeva 2, 10000 Zagreb, Croatia

E-mail: ivan.budimir@grf.hr

prof. dr. sc. Nikola Mrvac

Faculty of Graphic Arts

Getaldićeva 2, 10000 Zagreb, Croatia

E-mail: nikola.mrvac@grf.hr 